\title{
Trichothiodystrophy-neurotrichocutaneous syndrome of Pollitt: a report of two unrelated cases
}

\author{
M D KING*, C L GUMMER †, AND J B P STEPHENSON* \\ From * Fraser of Allander Assessment Unit, Royal Hospital for Sick Children, Yorkhill, Glasgow; and \\ $\dagger$ Department of Dermatology, Slade Hospital, Oxford.
}

SUMMARY Two unrelated children presenting with mental and physical retardation and sulphur deficient brittle hair are reported. These are thought to be further cases of the autosomal recessive neurotrichocutaneous syndrome of Pollitt, of which eight cases have been previously reported.

Trichorrhexis nodosa may be a useful marker for inherited metabolic disease and has been described in patients with argininosuccinic aciduria, Menkes' disease, biotin deficiency, ${ }^{1}$ and in a disorder first described by Pollitt et $a l^{2}$ in which sulphur deficient brittle hair was associated with mental and physical retardation in two sibs. Price $e t a l^{3}$ coined the term trichothiodystrophy for this syndrome and outlined the main features: sulphur deficient brittle hair, ichthyosis, nail dystrophy, dental caries, cataracts, involvement of the central nervous system, and decreased fertility. It was suggested that the hair shaft abnormality is diagnostic and that the clinical features may be due to a defect in transport or utilisation of sulphur-containing amino acids, with an autosomal recessive mode of inheritance.

We describe two unrelated children with this disorder in the second report from the United Kingdom, emphasising the neurological and hair shaft abnormalities.

\section{Case reports}

\section{CASE 1}

A boy, the second child of healthy unrelated Scottish parents aged 22 and 23 years, was born at term after an uneventful pregnancy, weighing $2.5 \mathrm{~kg}$, length $52 \mathrm{~cm}$, and head circumference $34.5 \mathrm{~cm}$. At birth, the hair was short, black, and woolly and fell out easily. At 6 months the child was referred to the Royal Hospital for Sick Children for investigation of suspected developmental delay and failure to thrive. On examination, length, weight, and head circumference were below the 3 rd centile. The face was unusual with receding chin and protruding ears. The skin was ichthyotic with

Received for publication 1 December 1983. Accepted for publication 20 January 1984. severe flexural eczema. The hair was short, dark brown in colour, dry and uneven, easily broken, and with patches of alopecia (fig 1). The eyebrows were short and stubbly, but the eyelashes were normal. The nails were hypoplastic and spoon shaped. Jerky ocular pursuit movements with titubation of the head, spastic diplegia, and extensor plantar responses were present. All deep tendon reflexes were absent. The fundi, lens, and conjunctivae were normal.

Over the following 3 years there was little mental or physical development. At 4 years (fig 1) the child is profoundly retarded, functioning at a 9 month level on the Cattell Infant Intelligence scale. Height, weight, and head circumference remain below the 3rd centile. The trichocutaneous findings are unchanged but, in addition, the skin is extremely

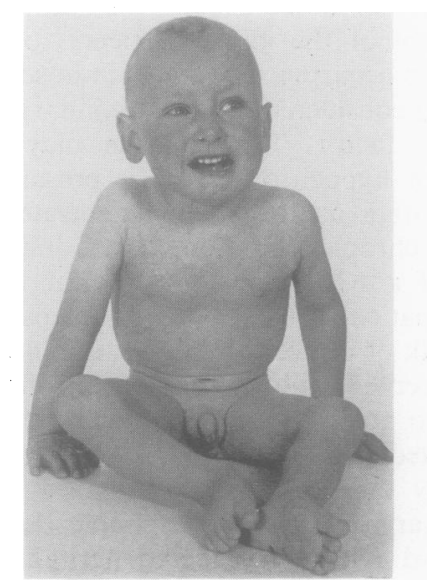

FIG 1 Case 1 aged 4 years: unusual face, protruding ears, and short stubbly hair with patches of alopecia. 
photosensitive. The child is able to sit unsupported but cannot crawl. Truncal ataxia, head titubation, spastic diplegia, and jerky movements persist.

\section{CASE 2}

A female, the first child of healthy non-consanguineous Scottish parents aged 20 and 23 years, was born at term after an uneventful pregnancy. Birth weight was $3 \mathrm{~kg}$, length $51 \mathrm{~cm}$, and head circumference $35 \mathrm{~cm}$. The patient was transferred to the Royal Hospital for Sick Children at 4 months, once similarity to case 1 had been recognised. She had jerky eye movements, limb stiffness, and failure to thrive. On examination the length, weight, and head circumference were below the 3 rd centile. The face was unusual and the hair was dark brown, sparse, and brittle. The eyebrows were short and stubbly, the upper eyelashes were normal, and the lower eyelashes were sparse. The nails were hypoplastic and spoon shaped. The skin was dry and photosensitive. Bilateral central nuclear cataracts, head lag, adductor spasm, scissoring of the lower limbs, and brisk tendon reflexes were found. The optic fundi were normal. At $2 \frac{1}{2}$ years the child functions at an 18 month level, crawls, walks with support, but has marked truncal ataxia and pyramidal signs as described at 4 months. Height, weight, and head circumference are $2 \mathrm{SD}$ below the 3 rd centile. The trichocutaneous features are unchanged (fig 2).

\section{INVESTIGATIONS}

The following investigations were normal in both patients: full blood count, plasma urea, electrolytes, ammonia, copper, caeruloplasmin, zinc, immunoglobulins, leucocyte enzymes ( $\beta$ galactosidase, $\beta$ glucuronidase, arylsulphatase $\mathrm{A}$, hexosaminidase $\mathrm{A}$ and B), hydrogen peroxidase test, plasma and urinary amino acids, urinary organic acids, cerebrospinal fluid cells and proteins, chromosomes by Giemsa banding, and electroencephalogram. Muscle

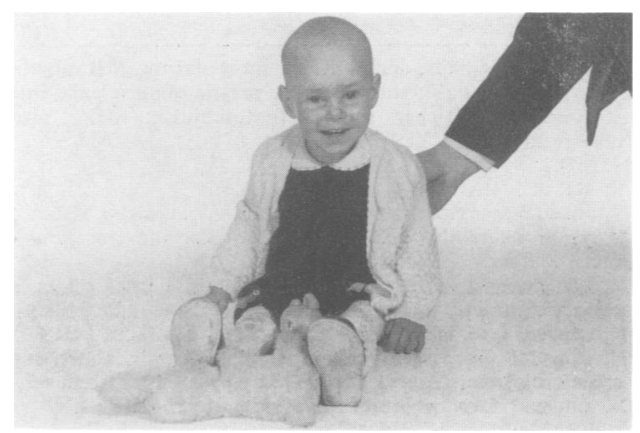

FIG 2 Case 2 aged $2 \frac{1}{2}$ years: unusual face and short stubbly hair. (quadriceps) and nerve (sural) biopsies (case 1 only) were normal, but motor nerve conduction velocity at the ages of 6,14 , and 24 months was slowed at $14 \mathrm{~m} / \mathrm{sec}$ in the lateral popliteal nerve in case 1 (normal 35 to $40 \mathrm{~m} / \mathrm{sec}$ ). Skin biopsy in case 1 was reported to show histological changes consistent with autosomal dominant ichthyosis. Nerve conduction velocities in both parents of case 1 were normal. Scalp hair from both patients was examined with light, polarising, and transmission electron microscopy. The findings were identical in both patients.

\section{MICROSCOPY OF HAIR SHAFT \\ Transmitted light}

The hair appears laterally flattened and flops into twists. The twists are analogous to the twisting of a

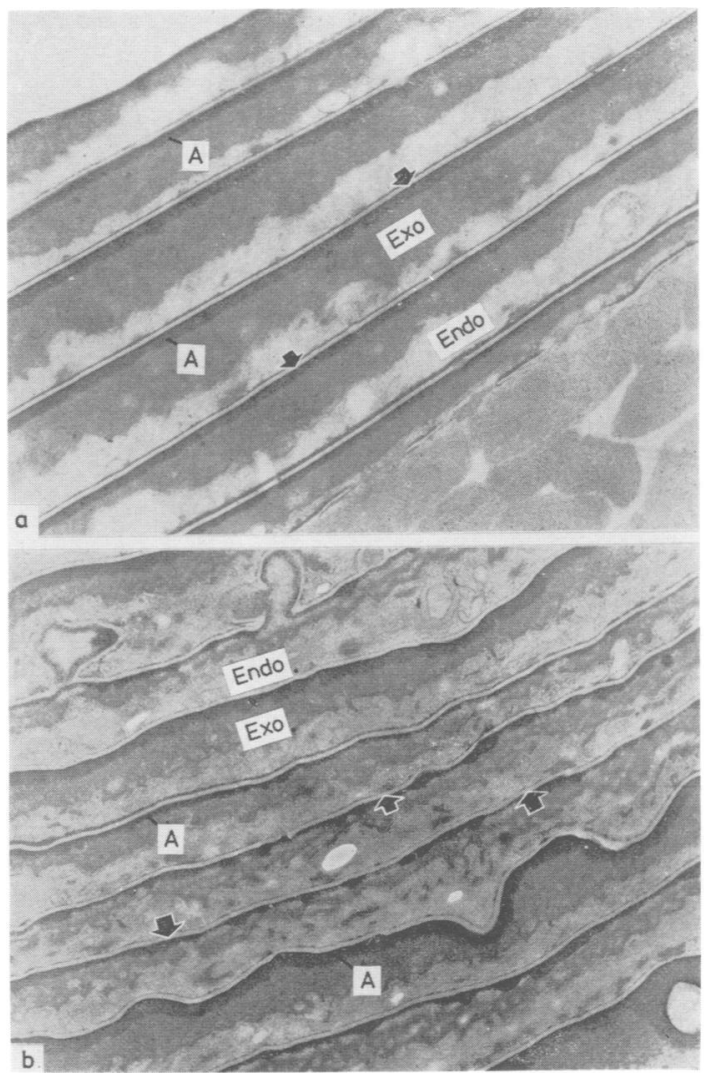

FIG 3 (a) Transverse section of normal hair cuticle showing regular layers of cuticle cells. (b) Transverse section of trichothiodystrophy hair cuticle showing marked variations in the component structures of adjacent cells. $A=$ a layer; Exo=exocuticle; Endo $=$ endocuticle $;$ arrows $=$ cell membrane complex. Stain=ammoniacal silver nitrate. 
ribbon and not to the twisting characteristics of pili torti. The hair cuticle shows an advanced degree of weathering (damage) along the length of the shaft with some areas showing complete loss of cuticle cells. Many hairs show transverse fractures and trichorrhexis type nodes, the hair shafts often ending in 'brush breaks'.

\section{Polarised light}

The appearance of the hair is abnormal. The hair ranges from an unstructured, white birefringence through to a structured birefringence of alternating light and dark bands of differing dichroic colours giving a zigzag appearance. By rotating the specimen relative to the crossed polars, the alternating light and dark bands may be reversed. Ultrastructurally this represents a failure of the fibrillar cortical proteins to align parallel to the longitudinal axis of the hair shaft.

\section{Transmission electron microscopy}

When stained with ammoniacal silver nitrate, a stain specific for the sulphur (cystine) rich components of the hair shaft, ${ }^{4}$ the cuticle a layer and exocuticle (normally rich in cystine) stain weakly with poor delineation of the lamellar sub-structure (fig 3). The cortex shows virtually no uptake of silver based stains confirming a deficiency of high sulphur matrix proteins.

Microscopy of hair shafts from both sets of parents and a sib of case 1 revealed no abnormality.

\section{Discussion}

Both cases described shared several clinical features: developmental delay, growth retardation, spasticity, cerebellar ataxia, jerky eye movements, photosensitive skin, dysplastic nails, and sulphur deficient brittle hair. Postnatal somatic and head growth retardation was striking in both patients. Cataracts, present in case 2, a less severely retarded child, were not found in case 1 who displayed peripheral neuropathy not seen in case 2 .

The cases of Pollitt syndrome reported to date are summarised in the table. All had low hair cystine with varying involvement of the nervous system, skin, nails, teeth, and lens. The disorder does not appear to be a generalised disturbance of cystine metabolism, as plasma and urinary aminoacids are normal in these patients. In addition, cystinurics in negative cystine balance have normal hair (personal observation). The hair shaft abnormality is most likely to be a secondary effect of some undefined biochemical abnormality in which there is a generalised disturbance in development of ectodermal tissues.

An explanation for the neurological involvement in Pollitt syndrome is not yet apparent. Lazarides ${ }^{9}$ described a relationship between keratin filaments of epithelial cells, neurofilaments of neurones, and glial filaments of astrocytes, and it is possible that the neurological features are caused by the same biochemical disturbance as affects hair shaft formation. Frontal lobe biopsy in the only patient with seizures showed abnormal cytoarchitecture with poorly defined layering of the cortical neurones. ${ }^{1}$ Further studies of cystine content and sulphur metabolism in nervous tissues may clarify these aspects.

The large family study by Jackson et $a l^{5}$ and the intermediate hair cystine content in a parent of a patient reported by Arbisser $e a^{6} l^{6}$ suggest that this disorder is inherited in an autosomal recessive fashion. A chromosomal abnormality (deletion of the long arm of chromosome 14) was detected in only one patient. ${ }^{5}$ It is possible that a single deletion

TABLE Summary of clinical features in all cases of Pollitt syndrome reported to date.

\begin{tabular}{|c|c|c|c|c|}
\hline Author & $\operatorname{Age}(y r)$ & $\operatorname{Sex}$ & Family history & Clinical features \\
\hline $\begin{array}{l}\text { Pollitt et al }{ }^{2} \\
\text { Jackson et al } \\
\quad \text { (also Coulter et al, } 1 \text { case } 1 \text { ) }\end{array}$ & $\begin{array}{r}5 \\
27\end{array}$ & $\begin{array}{l}\mathbf{F} \\
\mathbf{M}\end{array}$ & $\begin{array}{l}+ \\
+\end{array}$ & $\begin{array}{l}\text { TN, hypoplastic nails, dental caries, short stature, MR, ataxia } \\
\text { TN, hypoplastic nails, short stature, spastic quadriplegia, internal } \\
\text { strabismus, cleft ear lobes, cryptorchidism, MR, seizures, } \\
\text { abnormal EEG }\end{array}$ \\
\hline Arbisser et al 6 & $\begin{array}{l}5 \text { months } \\
5\end{array}$ & $\begin{array}{l}\mathbf{F} \\
\mathbf{M}\end{array}$ & $\begin{array}{l}+ \\
+\end{array}$ & $\begin{array}{l}\text { TN, MR } \\
\text { TN, MR }\end{array}$ \\
\hline \multirow{2}{*}{$\begin{array}{l}\text { Jorizzo et al } \\
\text { Price et } \text { al }^{3}\end{array}$} & 20 & $\mathbf{F}$ & - & TN, unusual face, ichthyosis, short stature, cataracts, MR \\
\hline & 5 & $\mathbf{M}$ & - & $\begin{array}{l}\text { TN, progeria, ichthyosis, hypoplastic nails, short- stature, cata- } \\
\text { racts, MR } \\
\text { TN, progeria, ichthyosis, hypoplastic nails, dental caries, short } \\
\text { stature, cataracts, tremor, hemiparesis, MR }\end{array}$ \\
\hline \multirow{3}{*}{$\begin{array}{l}\text { Jorizzo et al } 8 \\
\text { Present report }\end{array}$} & 8 & $\mathbf{M}$ & - & TN, unusual face, ichthyosis, short stature, cataracts, MR \\
\hline & 4 & $\mathbf{M}$ & - & $\begin{array}{l}\text { TN, unusual face, ichthyosis, hypoplastic nails, short stature, } \\
\text { spastic diplegia, truncal ataxia, jerky eyes, absent reflexes, MR }\end{array}$ \\
\hline & $2 \frac{1}{2}$ & $\mathbf{F}$ & - & $\begin{array}{l}\text { TN, unusual face, photosensitive skin, hypoplastic nails, short } \\
\text { stature, adductor spasm, truncal ataxia, jerky eyes, cata- } \\
\text { racts, MR }\end{array}$ \\
\hline
\end{tabular}

$\mathrm{TN}=$ trichorrhexis nodosa. $\mathrm{MR}=$ mental retardation. 
of genes essential to development of hair and brain underlies this disorder.

In the 14 years since the first and only published report of this disorder so far in Great Britain, there have been six reports from the United States. It may be that awareness regarding this obscure condition is lacking and it is hoped that this report of two cases seen at this hospital may stimulate further interest and investigation into the underlying defect.

\section{References}

1 Coulter DL, Beals TF, Allen RJ. Neurotrichosis: hairshaft abnormalities associated with neurological diseases. Dev Med Child Neurol 1982;24:634-44.

2 Pollitt RJ, Jenner FA, Davies M. Sibs with mental and physical retardation and trichorrhexis nodosa with abnormal amino acid composition of the hair. Arch Dis Child $1968 ; 43: 211-6$.

3 Price VH, Odom RB, Ward WH, Jones FT. Trichothiodystrophy. Arch Dermatol 1980;116:1375-84.
4 Swift JA. Electron histochemistry of cystine containing proteins in thin transverse sections of human hair. $J$ R Microsc Soc 1968;88:449-60.

5 Jackson CE, Weiss L, Watson JHL. 'Brittle' hair with short stature, intellectual impairment and decreased fertility: an autosomal recessive syndrome in an Amish kindred. Pediatrics 1974;54:201-7.

6 Arbisser AI, Scott CI, Howell RR, Ong PS, Cox HL. A syndrome manifested by brittle hair with morphologic and biochemical abnormalities, developmental delay and normal stature. Birth Defects 1976;12:219-28.

7 Jorizzo JL, Crounse RG, Wheeler CE. Lamellar ichthyosis, dwarfism, mental retardation and hair shaft abnormalities. J Am Acad Dermatol 1980;2:309.

8 Jorizzo JL, Atherton DJ, Crounse RG, Wells RS. Ichthyosis, brittle hair, impaired intelligence, decreased fertility and short stature (IBIDS syndrome). Br J Dermatol 1982;106:705-10.

9 Lazarides E. Intermediate filaments as mechanical integrators of cellular space. Nature 1980;283:249-56.

Correspondence and requests for reprints to $\mathrm{Dr}$ M D King, Fraser of Allander Assessment Unit, Royal Hospital for Sick Children, Yorkhill, Glasgow G3 8SJ. 